\title{
Short-term capture-based aquaculture of Atlantic cod (Gadus morhua L.) generates good physicochemical properties and high sensory quality during frozen storage
}

Sørensen, Jonas Steenholdt; Bøknæs, Niels; Mejlholm, Ole; Heia, Karsten; Dalgaard, Paw; Jessen, Flemming

Published in:

Innovative Food Science and Emerging Technologies

Link to article, DOI:

10.1016/j.ifset.2020.102434

Publication date:

2020

Document Version

Peer reviewed version

Link back to DTU Orbit

Citation (APA):

Sørensen, J. S., Bøknæs, N., Mejlholm, O., Heia, K., Dalgaard, P., \& Jessen, F. (2020). Short-term capturebased aquaculture of Atlantic cod (Gadus morhua L.) generates good physicochemical properties and high sensory quality during frozen storage. Innovative Food Science and Emerging Technologies, 65, [102434]. https://doi.org/10.1016/.ifset.2020.102434

\section{General rights}

Copyright and moral rights for the publications made accessible in the public portal are retained by the authors and/or other copyright owners and it is a condition of accessing publications that users recognise and abide by the legal requirements associated with these rights.

- Users may download and print one copy of any publication from the public portal for the purpose of private study or research.

- You may not further distribute the material or use it for any profit-making activity or commercial gain

- You may freely distribute the URL identifying the publication in the public portal 


\section{Journal Pre-proof}

Short-term capture-based aquaculture of Atlantic cod (Gadus morhua L.) generates good physicochemical properties and high sensory quality during frozen storage

Jonas Steenholdt Sørensen, Niels Bøknæs, Ole Mejlholm, Karsten Heia, Paw Dalgaard, Flemming Jessen

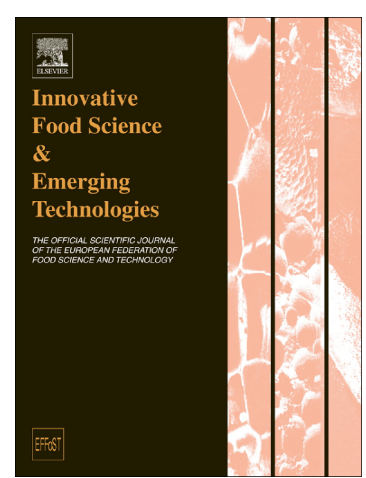
PII: $\quad$ S1466-8564(20)30380-5
DOI: $\quad$ https://doi.org/10.1016/j.ifset.2020.102434
Reference: $\quad$ INNFOO 102434

To appear in: Innovative Food Science and Emerging Technologies

Received date: $\quad 30$ March 2020

Revised date: $\quad 23$ June 2020

Accepted date: $\quad 24$ June 2020

Please cite this article as: J.S. Sørensen, N. Bøknæs, O. Mejlholm, et al., Short-term capture-based aquaculture of Atlantic cod (Gadus morhua L.) generates good physicochemical properties and high sensory quality during frozen storage, Innovative Food Science and Emerging Technologies (2020), https://doi.org/10.1016/ j.ifset.2020.102434

This is a PDF file of an article that has undergone enhancements after acceptance, such as the addition of a cover page and metadata, and formatting for readability, but it is not yet the definitive version of record. This version will undergo additional copyediting, typesetting and review before it is published in its final form, but we are providing this version to give early visibility of the article. Please note that, during the production process, errors may be discovered which could affect the content, and all legal disclaimers that apply to the journal pertain.

(C) 2020 Published by Elsevier. 
Short-term capture-based aquaculture of Atlantic cod (Gadus morhua L.) generates good physicochemical properties and high sensory quality during frozen storage.

Jonas Steenholdt Sørensen ${ }^{1,2}$, Niels Bøknæs ${ }^{2}$, Ole Mejlholm², Karsten Heia ${ }^{3}$, Paw Dalgaard ${ }^{1}$ and Flemming Jessen ${ }^{1}$

${ }^{1}$ National Food Institute (DTU Food), Technical University of Denmark, Kgs. Lyngby, Denmark

${ }^{2}$ Royal Greenland Seafood A/S, Svenstrup J, Denmark

${ }^{3}$ Nofima, Troms $\varnothing$, Norway

* Corresponding author: Food Microbiology and Hygiene, National Food Institute, Technical University of Denmark, Kemitorvet, Building 202, 2800, Kgs. Lyngby, Denmark. E-mail: jonsor@food.dtu.dk 


\section{Abstract}

The annual global catch of Atlantic cod (Gadus morhua L.) is above $1,000,000$ tons, and a large proportion is preserved and sold as frozen products. In Greenland, a new innovative fishing method centred on capture-based aquaculture has been developed. To compare the new fishing and processing method with the conventional method, the texture, colour, water holding capacity, salt soluble proteins and sensory properties of fillets were evaluated during 12 months of frozen storage. High quality life (HQL) and practical storage life (PSL) were determined for each fishing and processing method based on sensory evaluation, and by using water holding capacity and the salt soluble protein fraction as indices of quality. Capture-based aquaculture fishing and related processing increased frozen storage durability regarding texture attributes, blood content and sensory properties compared to the conventional method. Lowering the storage temperature to $-40{ }^{\circ} \mathrm{C}$ increase the $\mathrm{HQL}$ to $>12$ months compared to a HQL of 4-6 months at $-20^{\circ} \mathrm{C}$.

Keywords: Durability study, salt soluble protein, water holding capacity, texture profile analysis (TPA), Greenland, shelf-life 


\section{Introduction}

Atlantic cod (Gadus morhua L.) has been one of the most important commercially fished species for more than a century. The annual global catch of wild cod has been above 1,000,000 tons, except for the years 2000-2010 (FAO, 2020). In the period 2006 to 2012, attempts were made to farm cod and aquaculture production that reached 22,728 tons in 2009 has since collapsed (FAO, 2020; Henriksen, Heide, Hansen, \& Mortensen, 2018). Capture-based aquaculture (CBA) was a new fishing method for Atlantic cod fishery that keeps the fish alive after capture and during transport to holding nets adjacent to a processing plant. The live fish were then available for slaughter in a non-stressed state and quantities matching the production capacity can be taken from the holding nets. In addition, CBA combined with holding live fish in net enclosures gave the possibility for rapid processing and packaging, both for frozen or wholesale distribution of fresh cod (Sønvisen \& Standal, 2019). In Norway, adult cod was captured during the winter and kept alive for processing in the late spring and summer. The main driver was to reduce seasonality of the landings to stabilise prices throughout the year (Hermansen \& Eide, 2013). Furthermore, rested and rapidly processed cod from CBA has a long shelf-life and limited microbial growth when superchilled at $-1.7^{\circ} \mathrm{C}$ (Sørensen, Bøknæs, Mejlholm, \& Dalgaard, 2020a) and after frozen storage the thawed CBA cod has a low drip loss and long chilled shelf-life when stored in modified atmosphere packaging (Sørensen, Ørnfeld-Jensen, Bøknæs, Mejlholm, Jessen, \& Dalgaard, 2020b). With CBA, cod was not typically fed after the catch, and some degree of starvation takes place. A starvation period of no longer than 54 days has been recommended (Ageeva, Jobling, Olsen, \& Esaiassen, 2017). For salmon and carp, with an empty gut, the metabolic and physical activity was reduced (Jobling, 1981), which leads to reduced stress during handing and pumping and thereby reduced mortality (the Farm Animal Welfare Committee (FAWC), 2014; Waagbø, Jørgensen, Timmerhaus, Breck, \& Olsvik, 2017). Within the first 54 days of starvation, no significant sensory or physicochemical changes occurred in the fillet (Ageeva, Olsen, Joensen, \& Esaiassen, 2018). 
Greenland and Newfoundland have a long history of cod fishing with large quantities of fish and long distances to the primary markets in Europe. Traditionally salting and later freezing were used to preserve cod during the long transportation from the Northwest Atlantic to Europe (Cole, 1990). Freezing and frozen storage of cod below $-10{ }^{\circ} \mathrm{C}$ inhibit the microbial spoilage (Ratkowsky, Olley, McMeekin, \& Ball, 1982), while the autolytic and chemical reactions may occur at slow rates for Atlantic cod (Rehbein, 1988). Protein denaturation and dehydration are the main spoilage reactions that determine the frozen storage shelf-life when the temperature was below $-10{ }^{\circ} \mathrm{C}$ (Torry Research Station, 2001). Protein changes during frozen storage depend on the frozen storage temperature (Burgaard \& Jørgensen, 2010) and temperature variability during frozen storage (LeBlanc, LeBlanc, \& Blum, 1988). It has been suggested that temperatures below $-28{ }^{\circ} \mathrm{C}$ can prolong the frozen shelf-life to four years before white fish become inedible compared to 15 months when stored at $-21{ }^{\circ} \mathrm{C}$ (Torry Research Station, 2001). Furthermore, storage at -5 to $-15{ }^{\circ} \mathrm{C}$ resulted in markedly reduced shelf-life due to enzymatic formaldehyde formation from trimethylamine oxide (TMAO) (LeBlanc \& LeBlanc, 1988). However, we have found no previous studies of storage durability of CBA produced cod nor how frozen storage temperature influences the shelf-life.

The cod fishery in West Greenland occurs primary inshore, with small vessels setting pound nets during the period from May to November when the cod follow their primary feedstock of capelin close to the shore (Statistics Greenland, 2019). On-board freezing facilities were not available on these small day-boats, and they bring their catch to a local processing and freezing plant. Different challenges were related to the processing and distribution of high-quality cod products from this fishery. Firstly, the time from catch to bleeding and slaughter may be longer than optimal due to limited capacity on the small vessels. Secondly, in high season, quantities of iced cod delivered to processing plants may be larger than what their filleting and freezing capacity can handle leading to storage of whole gutted cod in ice for several days prior to processing. Consequently, frozen whole cod from this fishery can have soft 
texture after thawing resulting in lower filleting yield and profit losses (Personal communication, Royal Greenland).

The objective of the present study was to evaluate the effect on frozen storage shelf-life at $-20^{\circ}$ C of cod fillets from a newly developed process involving CBA of cod and to compare with the conventional processing in Greenland. A durability study of frozen storage with cod fillets was performed to determine shelf-life based on sensory changes and changes of colour, texture and other physicochemical characteristics and to compare the two types of cod processing. Additionally, the effect of frozen storage at $-20,-40$ and $-80{ }^{\circ} \mathrm{C}$ on shelf-life and quality attributes for cod fillets from CBA was investigated.

\section{Materials and methods}

\subsection{Materials}

Atlantic cod (Gadus morhua L.) were conventionally caught with pond nets close to the shoreline of West Greenland. This fishing with pond nets is a passive fishing method, as the fish are trapped in net enclosures. From the net enclosure, the cod were processed either by a conventional method (2.1.1) or by a new short term capture-based aquaculture (CBA) processing method (2.1.2).

\subsubsection{Conventional processing method}

Fish caught in pound nets were brought to the surface by pulling the net into the fishing vessel and the cod was trapped in a confined space. From there, the fish were then hand-picked, throat cut, eviscerated, and bleed in the air at the bottom of the small open surface vessels. At the end of this processing, the cod were packed in fish boxes and covered with ice (Fig. 1A). From the fjords, the fish 
were then transported to a nearby processing plant. At the processing plant, the two first days after landing of the fish, no further processing could be performed as the rigor mortis process had to end prior to machine filleting. The post-rigor mortis cod were processed by machine decapitation (Baader 417, Lübeck, Germany) and filleted (Baader 192, Lübeck, Germany). The fillets were hand-trimmed and individually quick frozen (IQF) as skin-on fillet using a gyro freezer (Carnitech, Støvring, Denmark) with a 10 $\%(w / w)$ protective glaze layer of water.

\subsubsection{Short term capture-based aquaculture (CBA) processing method}

After being caught by pond nets (Fig. 1A), the fish was gently and alive lead into a transportable net enclosure without leaving the water at any point and then kept alive for two to three weeks to reduce their stomach content (Fig. 1B). The starved cod was pumped up to a well-boat, and all cod smaller than $42 \mathrm{~cm}$ were released directly to the fjord $(42 \mathrm{~cm}$ was the minimum cod landing size in Greenland in 2018) (Fig. 1C). The well-boat transported the cod to the processing plant, where the fish was pump into a large ocean net enclosure adjacent to the processing plant (Fig. 1D). At this step, the cod was kept for a minimum of 12 hours to recover from transportation and handling stress. The rested cod was pumped into the processing plant at a rate corresponding to the workforce and production capacity of a given day and then stunned immediately after exposure to the air. The stunning was performed by electricity ( $20 \mathrm{~V}, 400 \mathrm{~Hz}$ for 5 seconds) and the cod was slaughtered by decapitation (Baader 417, Lübeck, Germany). The viscera were removed by hand and the headed and gutted cod was bleed for $30 \mathrm{~min}$. in circulating water at $3-5^{\circ} \mathrm{C}$. The fish was then placed 30 - 60 minutes in ice water to reduce the muscle tension created by ATP activation of the action potential (Hibberd \& Trentham, 1986), but not long enough for the rigor-mortis stiffness to begin. The cod was machine filleted (Baader 
192, Lubeck; Germany) and hand-trimmed followed by freezing as IQF fillets in the same way as described for the conventional method (See 2.1.1).

\subsubsection{Transport to DTU Food}

In early June 2018, fish caught by the conventional (2.1.1) and CBA (2.1.2) processing methods, were transported by ship from Greenland to Denmark. The cod arrived in Denmark one month after slaughter and processing. During transport from Greenland to DTU Food, the temperature of the cod fillets was recorded regularly by loggers (TinyTag Plus, Gemini Data Loggers Ltd., Chichester, UK) and the average storage temperature was $-21.2^{\circ} \mathrm{C} \pm 0.1(\mathrm{SD})$, and it never exceeded $-16.2^{\circ} \mathrm{C}$.

\subsection{Experimental plan and analyses}

\subsubsection{Experimental plan}

From arrival at DTU Food, the conventionally produced fillets were stored at $-20{ }^{\circ} \mathrm{C}$ (i). Fillets from CBA were randomly split into three groups, that were stored at $-20^{\circ} \mathrm{C}$ (ii), $-40{ }^{\circ} \mathrm{C}$ (iii) and $-80{ }^{\circ} \mathrm{C}$ (iv), respectively. After storage for three, six, nine and 12 months, eight cod fillets from each treatment (i-iv) were analysed. The fillets were thawed overnight in a $2{ }^{\circ} \mathrm{C}$ cooling room, and the thawed fillets were cut into loin (Fig. 2A) and tail parts (Fig. 2B). The loin parts were studied by image analyses (2.2.2), texture (2.2.3), water holding capacity (2.2.4), and salt soluble proteins (2.2.4) in that order. The tail parts were studied by image analyses (2.2.2).

Using four different fillets from each treatment (i, ii, iii and iv) sensory profiling (2.2.5) was conducted by Royal Greenland Seafood A/S, after three, six, nine, 12, and 15 months of frozen storage. 


\subsubsection{Hyperspectral imaging (HSI)}

HSI was performed with a VideometerLab 2 (VideometerLab 2, version 2.13.54, Videometer A/S, Denmark) installed with 18 channels from $375 \mathrm{~nm}$ to $1050 \mathrm{~nm}$. Before the experiment, a series of HSI of cod from different production dates were taken to optimise the exposure time of each channel and saved as the systematic light setting for the colour analyse. The system was calibrated radiometrically using a diffuse white, dark and geometrical disc before each sampling point. The samples (loin and tail, Fig. $2 \mathrm{~A}$ and $2 \mathrm{~B}$ ) were placed in a plastic petri dish, and the HSI picture was taken, using the software provided by Videometer. The HSI spectra were transformed to daylight50 CIELab colour space and processed with the software accommodating the Videometer (VideometerLab 2, version 2.13.54, Videometer $A / S$, Denmark) to obtain the average $L, a^{*}$ and $b^{*}$ values for each fillet using MATLAB (R2018b, The Mathworks Inc., MA, USA).

\subsubsection{Blood content by HSI analysis}

The quantification of blood in the fillets was analysed using an indirect method for the Videometer HSI from three and six months of storage. The 18 channel HSI was converted from a reflectance spectrum into an absorbance spectrum by using Eq. 1.

$$
\text { Absorbance }=\log (1 / \text { Reflectance }) \quad \text { Eq. } 1
$$

The obtained absorbance spectra were analysed using Nofima's software (IDL 8.71., Harris Geospatial Solution Inc., Colorado, USA) for quantitative estimation of blood in the surface of cod fillets based on a constrained spectral un-mixing approach (Skjelvareid, Heia, Olsen, \& Stormo, 2017). In addition to HSI obtained from the Videometer, four whole fillets (stored for nine months) for each 
treatment were transported from DTU Food to Nofima (Troms $\varnothing$, Norway). A high-resolution HSI were taken using a VNIR-1024 imaging spectrograph (Norsk Elektro Optikk, Skedsmokorset, Norway), operated in a push broom imaging mode. The imaging was performed in an interactance setup, that means that the fillets are illuminated with two focussed light lines. The HSI measured between the two light lines as the fillets were moving on a conveyor belt (speed $400 \mathrm{~mm} / \mathrm{s}$ ). In this way the light had to travel some distance inside the fillet before being recorded, giving an image of both the surface and the inside of the fillet. The spatial and spectral resolution was $0.28 \times 0.56 \mathrm{~mm}$ and $2.7 \mathrm{~nm}$ in the range of 410-990nm. Using a Teflon reference the HSI data can be transformed into absorbance and run through the constrained spectral unmixing analysis and the blood abundancies were recalculated into chemical blood concentration. (Skjelvareid et al., 2017).

\subsubsection{Texture profile analysis}

The loin part previously used for HSI was cut into two $4 \times 4 \times 2 \mathrm{~cm}$ muscle pieces (MP), and the texture profile analysis (TPA) was determined in duplicates for each fillet. The texture of the MP was measured using the TA.XTplus Texture Analyser (Stable Micro System, Surry, England) equipped with a $30 \mathrm{~kg}$ load cell. A P/75 compression plate compressed the MC to $50 \%$ of the total MC height, with a five $\mathrm{mm} / \mathrm{s}$ speed. Texture curves were recorded with a resolution of 200 points/s and analysed by the instrumental software (Texture Exponent, Version 6.1.15, Stable Micro System, Surry, England). From the time-force graphs, the TPA parameters, hardness, resilience and springiness were calculated by the software of the instrument (Chandra and Shamasundar, 2015).

\subsubsection{Water holding capacity and salt soluble proteins}


The loin used for TPA were blended for 5 seconds using a kitchen table blender, and the blended loin was used to determine dry matter (DM), water holding capacity (WHC) and salt soluble proteins (SSP). DM was measured as the percentage of remaining mass after 24 hours drying at $105^{\circ} \mathrm{C}$ in relation to the two grams wet weight of loin and performed in duplicates. WHC was measured in quadruples, by weighing two gram of the blended fillet into a cylindrical poly methyl-methacrylate tube (inner diameter of $25 \mathrm{~mm}$, fabricated at DTU Food) with a $102 \mu \mathrm{m}$ mesh size filter bottom (diameter of $19 \mathrm{~mm}$, nylon 100 HC, Preben-Z filterteknik, Hedehusende, Denmark) that allowed the liquid to pass through. The cylindrical tube was placed on top of 40 gram of glass marbles in a centrifuge tube as illustrated in Eide, Børresen, \& Strøm (1982) and centrifuged as described in Burgaard \& Jørgensen (2010). The WHC was expressed as the water retention from the original water content and was calculated by Eq. 2. Where $\Delta r$ is the \% of mass difference of the sample before and after centrifugation.

$$
W H C \%=\frac{100-D M-\Delta \mathrm{r}}{100-D M} \times 100 \quad \text { Eq. } 2
$$

SSP was quantified by determining the fraction of proteins dissolved in a salt solution to the total protein in the muscle (Dyer, French, \& Snow, 1950). The proteins were dissolved in a salt solution, $1.75 \mathrm{~g}$ of blended loin muscle was mixed for 3 minutes (Ultra-Turrax, 8,500 rpm) with a salt solution prepared in a measurement cylinder. In a $50 \mathrm{~mL}$ cylinder, $30 \mathrm{~mL}$ of $0.86 \mathrm{M} \mathrm{NaCl}$ and $0.6 \mathrm{M} \mathrm{NaHCO}$ (pH of 7.4), cooled with ice, was topped to the $35 \mathrm{~mL}$ mark with flake ice. The mixture was centrifuged at 10,000 g for 20 minutes at $4^{\circ} \mathrm{C}$ (Sigma 4-16KS, Sigma Laborzentrifugen $\mathrm{GmbH}$, Osterode am Harz, Germany). The supernatant of the sample was filtered through a metal tea filter and stored at $-20{ }^{\circ} \mathrm{C}$ until further analysis. The protein, both the total protein content of the fillet and the protein content in the salt solution, was measured as the nitrogen value determined by the Dumas combustion procedure (Etheridge, Pesti, \& Foster, 1998). The parameters of the combustion profiles were optimised for the nitrogen value of the samples. For total protein in the muscle, $0.2 \mathrm{~g}$ sample was combusted with 300 
$\mathrm{mL} / \mathrm{min} \mathrm{O}_{2}$ for 120 seconds and the salt solution, $2.5 \mathrm{~g}$ sample was combusted with $150 \mathrm{~mL} / \mathrm{min} \mathrm{O}_{2}$ for 90 seconds and recorded with Rapid MAXn (Elementar, V.1.0.14, elementar Analysensteme GmbH, Langenselbold, Germany). The conversion rate between the nitrogen values and proteins was set to a factor of 6.25 .

\subsubsection{Sensory profiling analysis}

Quantitative descriptive analysis (QDA) as described by Stone, Sidel, Oliver, Woolsey, \& Singleton, (1974) was used to evaluate the sensory profile of cod fillets from different treatments and frozen storage times. Eight to thirteen tested and trained assessors from Royal Greenland Seafood A/S (RG), with extensive knowledge of seafood, were the base for the sensory panel. Fourteen attributes were previously chosen at RG to describe the sensory profile of cod. These included, visual and textural appearance (gaping, whiteness, frayed, firmness) and odour (fishy, ocean/seaweed) for raw cod. The cooked cod was assessed using odour (warm milky), texture (juiciness, toughness, flakiness) and flavour (sweet, metallic, fishiness, bitter) attributes. For each session, one raw and one cooked fillet of each treatment (i, ii, iii and iv) was evaluated and scored on an unstructured scale with the size of $100 \mathrm{~mm}$.

The cod fillets were shipped frozen from DTU Food to RG in Styrofoam boxes cooled with dry ice. At RG, the fillets were placed in a stainless steel container (1/1 gastronorm) and thawed overnight in a $2{ }^{\circ} \mathrm{C}$ refrigerator. The cooked fillets were heated with the skin side up in a preheated oven at $80{ }^{\circ} \mathrm{C}$ with $60 \%$ air circulation and steam for 8 minutes (SCC 61, Rational, Heerbrugg, Germany). The raw and cooked fillets were presented to the panel on stainless steel plates, and each product was given a random 3-digit number. 


\subsection{Data analysis}

To determine the blood content of fillets from the 18 channels Videometer HSI, these were transformed into a seven-channel HSI including three channels with information of blood concentration by an IDL widget application (IDL, Harris Geospatial Solution Inc., Colorado, USA). The region of interest (ROI) was picked by a MATLAB script (MATLAB R2018b, The MathWorks Inc., Massachusetts, USA) and RStudio was used for statistical analysis (RStudio Version 1.2.5001, Massachusetts, USA) for both HSI obtained from the Videometer and from Nofima's platform. Linear models (Im) in combination with ANOVA were used to check differences between frozen storage time and treatments, post hoc analysis in the form of the Tukey t-Test was used to analyse which treatments were significantly different. The analysis for the development of WHC, SSP, DM, texture and colour during storage were performed by using GraphPad Prism 8.3.0 (GraphPad Software, California, USA), with the build-in tool for simple linear regression including $\mathrm{F}$ ratio test and $\mathrm{P}$ value to test if the slope was significant different from zero. In case of a slope significantly different from zero, the mean of the values was analysed with two-way ANOVA. Principle component analysis (PCA) of the sensory data was performed with PanelCheck v1.4.2 (PanelCheck, 2012) and the raw PCA data was exported to Microsoft Excel 2016 to produce the graphs (Microsoft Corp., Redmond, WA, USA).

\section{Results}

\subsection{Sensory profiling}

The overall variation in the sensory quality of the cod was shown in Fig. $3 \mathrm{~A}$ as the scores of the first two principal components (PCs) from a PCA on the data from the sensory profiles. The main variation along with the PC 1 (70.6\% of the explained variance) showed that cod from the conventional processing after 12 and 15 months of storage was positioned in the right side of the scores plot 
separated from all the other treatments and sampling times (Fig. 3A). The scores plot in Fig. 3A also shows that in the PC 2 (7.0\% of explained variance) direction the CBA cod stored for 12 and 15 months at $-20{ }^{\circ} \mathrm{C}$ were positioned apart from (in the bottom of the plot) the $\mathrm{CBA}$ cod stored at $-40{ }^{\circ} \mathrm{C}$ and $-80{ }^{\circ} \mathrm{C}$ for 12 and 15 months. From the corresponding loading plot (Fig. 3B), it can be seen that the sensory attributes causing the variation in the PC 1 positive direction were mainly the texture attribute toughness and the flavour attribute metallic. In contrast, the negative direction was primarily associated with the texture attributes flakiness and juiciness and the flavour attribute sweet. In the PC 2 direction, the attributes responsible for most of the variation between samples were the appearance attribute firmness of the raw cod (negative direction) and the sweet flavour of the cooked cod (positive direction) (Fig. 3B).

Frozen shelf-life determined by sensory changes was defined in two ways, high-quality life (HQL) and practical storage life (PSL), with HQL as the time to reach a significant difference from the control sample and PSL as the time when the product was not acceptable (Bøgh-Sørensen, 2006). The just noticeable difference between the control sample (CBA cod at $-80^{\circ} \mathrm{C}$ ) and the conventionally processed cod, the CBA cod at $-20{ }^{\circ} \mathrm{C}$ and the $\mathrm{CBA}$ cod at $-40{ }^{\circ} \mathrm{C}$ gave a $\mathrm{HQL}$ of three to six months for the conventionally processed cod and the CBA cod stored at $-20^{\circ} \mathrm{C}$. Storage at $-40{ }^{\circ} \mathrm{C}$ extended the $\mathrm{HQL}$ for CBA cod to $>15$ months (Table 1). The PSL was defined by the time to reach unacceptable attributes (sweet, bitter, metallic and fishy). Compared to the control sample PSL was nine to 12 months for the conventional processed cod at $-20{ }^{\circ} \mathrm{C}$ extended to 12 to 15 months by switching to the CBA fishing method (Table 1).

After 15 months of storage, the scores for flakiness and juiciness were significantly lower in the conventionally processed cod compared to CBA $\operatorname{cod}(p<0.05)$ (Fig. 4A and 4B). On the contrary, toughness scores, as well as metallic taste scores, were significantly higher for conventional cod compared to CBA cod after 12 and 15 months $(p<0.01)$ of storage (Fig. 4C and 4D). The sweetness score 
decreased both in the conventional cod $(p<0.01)$ and in the CBA cod $(p<0.05)$ during storage at $-20^{\circ} \mathrm{C}$

(Fig. 4E). The firmness score in the conventional cod was lower than in the CBA cod (Fig. 4F) during most of the storage time, although this was exclusively shown to be significant $(p<0.05)$ after 3,12 and 15 months of storage.

\subsection{Blood content}

Frozen storage for three and six months did not affect the blood content in the cod (Conventional and CBA) $(p=0.79)$ and it was assumed that the blood content was independent of storage period, henceforth the HSI for nine and 12 months was not analysed for blood. For the CBA cod, the storage temperature did not affect the blood content $(p=0.93)$. All the obtained HSI spectra taken from the conventionally processed cod after three and six months of storage were pooled $(n=16)$, and so were the spectra from the CBA processed cod, independent of storage temperature $(n=48)$ and the two methods were compared. The comparison of the two processing methods showed a significantly lower blood content in the CBA cod compared to the conventionally produced cod, both for the loin and the tail regions of the fillet $(p<0.001)$. For both the conventionally and the CBA produced cod, the tail part contained significantly more blood than the loin part $(p<0.05)$. This was a result of a higher concentration of dark muscle fibers in the tail, which contain more blood compared to the white muscle fiber (Huss, 1995).

HSI of whole fillets, acquired with high-resolution VNIR, showed an even more clear difference in blood content between cod from the two processing methods $(p<0.0001, n=16$ with $n=4$ for conventional and $n=12$ for $(B A)$. The average blood content of conventionally processed cod was 0.09 $\mathrm{mg}$ haemoglobin/g muscle and $0.07 \mathrm{mg}$ haemoglobin/g muscle for CBA cod, both values within 
consumer acceptance. To illustrate the difference between the conventional and the CBA fishing method, an analysed HSI spectrum of a fillet from each method is presented in Fig. 5.

\subsection{Physiochemical changes during storage}

The WHC changed during storage as an effect of storage temperature, after nine months of storage, both the conventionally produced and the CBA cod stored at $-20^{\circ} \mathrm{C}$ had significantly lower WHC than CBA cod stored at $-40{ }^{\circ} \mathrm{C}$ and $-80{ }^{\circ} \mathrm{C}(\mathrm{p}<0.05)$ (Fig. 6A) and remained lower after 12 months of storage $(p<0.0001)$. No significant effect was observed between the two production methods, and no changes were found for the CBA cod when stored at the lower temperatures of $-40{ }^{\circ} \mathrm{C}$ and $-80{ }^{\circ} \mathrm{C}$ (Fig. 6A). Similar to WHC, the SSP was exclusively affected by storage temperature and not by the processing method. The SSP for CBA produced cod stored at $-40{ }^{\circ} \mathrm{C}$ and $-80^{\circ} \mathrm{C}$ did not change during storage and were after 12 months significantly $(p<0.05)$ higher than in cod stored at $-20^{\circ} \mathrm{C}$ (Fig. 6B).

\subsection{Texture changes during storage}

Comparing the two processes at $-20^{\circ} \mathrm{C}$, showed that $\mathrm{CBA}$ had an increased hardness of the loin and was significantly more firm after three and twelve months (Table 2). The conventional process resulted in a texture of significantly higher springiness throughout the storage period. Comparing the hardness of the loin stored at different temperatures did not show any significant difference for CBA cod at the same frozen storage time. However, the CBA cod stored at $-20{ }^{\circ} \mathrm{C}$ showed a significant increase in hardness during the storage period (Table 2). The springiness remained stable when stored at $-20{ }^{\circ} \mathrm{C}$, whereas, at lower temperatures, the springiness significantly decreased during the frozen storage time. 
The resilience of the cod did not change during storage, and there was no significant difference between the treatments (data not shown).

\subsection{Colour changes during storage}

The colour of the loin was influenced by the production method. The $L^{*}$ and $a^{*}$ value of CBA cod remained stable during the twelve months of storage, while the a* value of the conventionally processed cod showed a significant increase (Table 2). Storage of cod at $-40{ }^{\circ} \mathrm{C}$ or $-80{ }^{\circ} \mathrm{C}$ resulted in stable $b^{*}$ values during the entire storage period, whereas at $-20^{\circ} \mathrm{C}$ the $b^{*}$ value increased significantly during the storage.

\section{Discussion}

The two production methods included some fundamentally different processing steps of the frozen cod. In the CBA production, the cod was slaughtered in a rested state after a minimum of stress in the antemortem phase, and the fillets were frozen pre-rigor mortis. In the conventional production method, the cod was more stressed before slaughter, and the fillets were cut and frozen post-rigor mortis.

In the present study, the conventional method resulted in a softer fillet, with lower hardness scores, throughout the entire frozen storage period (Table 2). The harder texture found in the CBA cod could be caused by several factors, including starvation, time of filleting and stress. Olsson, Gundersen, \& Esaiassen (2006) showed that prolonging the starvation period from two to three weeks before slaughtering increased the hardness (shear force) of cod fillets after storage on ice for two weeks. The 
CBA cod from Greenland starved between two to four weeks in comparison to the conventional method, including no starvation of the cod.

In the conventional method, the cod goes through the rigor mortis process before filleting. With the muscle structure physically attached to the vertebrate frame of the fish during rigor mortis it results in more gaping compared to pre-rigor mortis filleted cod (Kristoffersen, Tobiassen, Steinsund, \& Olsen, 2006). The increased gaping observed by Kristoffersen et al. (2006) indicates that the connective tissue was broken and this may be a contributing factor to the softer fillet texture of the conventional method. Mørkøre, Hansen, \& Rørvik, (2006) showed that pre-rigor mortis filleting results in better sensory texture. The texture differences between stressed and rested cod had previously been reported, and it was found that the stressed cod (corresponding to the conventional cod in the present study, Table 2) had a softer texture (Hultmann, Phu, Tobiassen, Aas-Hansen, \& Rustad, 2012) compared to rested cod. However, others have shown no significant textural differences between the rested and stressed cod (Erikson, Digre, \& Misimi, 2011).

The differences in discolouration seen in the present study could be explained by the lower blood content found in fillets from CBA cod compare to the traditionally processed cod. It has been hypothesised that such a low blood content could be due to the combination of an optimal stunning practice, live storage and proper bleeding of the cod, three factors that have been addressed in the CBA production chain (Fig. 1). The stunning by electricity in the CBA method (Fig. 1D) has been investigated previously, and no adverse effect on sensory, $\mathrm{pH}$ and texture quality when compared to anaesthesia was found, which must be assumed to be the least stress-induced stunning method (Erikson et al., 2012). The increased redness and yellowness of fillets from the conventional fishing method (Table 2) might be related to induced stress antemortem. Studies have documented stress-induced discolouration, such as increased yellowness and redness in cod fillets (Hultmann et al., 2012; Jørpeland, Imsland, Stien, Bleie, \& Roth, 2015). A resting period after the stress has a positive influence on discolouration, and it has been 
shown that six hours live storage of cod captured by trawl was sufficient to avoid the stress-induced discolouration (Olsen, Tobiassen, Akse, Evensen, \& Midling, 2013). In this context, the importance of bleeding was underlined, although the type of bleeding method was unimportant (Olsen et al., 2014).

The storage temperature and duration of frozen storage has an impact on the enzyme activity in the muscle and on the ability of the proteins to dissolve in a $\mathrm{NaCl}$ solution. The $\mathrm{Ca}^{2+}$ ATPase activity was lost more rapid at $-20^{\circ} \mathrm{C}$ compared to $-30{ }^{\circ} \mathrm{C}$ (Godiksen, Hyldig, \& Jessen, 2003) and it is well known that the SSP fraction during higher frozen storage temperatures (e.g. $-10^{\circ} \mathrm{C},-15^{\circ} \mathrm{C}$ ) decreases fast. Lowering of the temperature to $-30{ }^{\circ} \mathrm{C}$ reduces this loss in protein solubility dramatically (Badii \& Howell, 2002a; Careche, Del Mazo, Torrejón, \& Tejada, 1998; Del Mazo, Torrejón, Careche, \& Tejada, 1999; LeBlanc \& LeBlanc, 1992). There is no common agreement between sensory shelf-life and the SSP faction and to compare studies, based on the sensory evaluation, we suggest a high quality life (HQL) and a practical storage life (PSL) criteria of $<70 \%$ SSP or $0.3 \mathrm{mg} \mathrm{SSP} \mathrm{g}^{-1}$ fish muscle and $<60 \%$ SSP or $0.2 \mathrm{mg} \mathrm{SSP} \mathrm{g}^{-1}$ fish muscle, respectively. Applying these criteria, gave a PSL at $-30{ }^{\circ} \mathrm{C}$ or below of more than 12 months in the present study (Table 1) and this period was supported by various studies with cod (Badii \& Howell, 2002b, 2002a; LeBlanc \& LeBlanc, 1992), hake (Del Mazo et al., 1999) and haddock (Badii \& Howell, 2002a). Increasing the storage temperature to $-20^{\circ} \mathrm{C}$ decreased the PSL to 10 months (Fig. $6 \mathrm{~B}$ ) which is similar to results from previous studies on hake and cod (Del Mazo et al., 1999; LeBlanc \& LeBlanc, 1992). A further increase of the temperature to $-10{ }^{\circ} \mathrm{C}$ resulted in a PSL around one month (Badii \& Howell, 2002b, 2002a).

The negative impact on the proteins during frozen storage, also affects the WHC of the muscle proteins. The freezing storage temperature and time have previously been shown to influence the WHC. Cod from the Barents Sea showed a significantly lower WHC after 12 months of storage at $-20{ }^{\circ} \mathrm{C}$ compared to $-30^{\circ} \mathrm{C}$ (Bøknæs et al., 2002). Bøknæs, Guldager, Østerberg, \& Nielsen, (2001) suggested a criterion for HQL of $70 \%$ WHC and a PSL of $60 \%$ WHC. In the present study, a HQL of $65 \%$ WHC was 
chosen as the initial WHC was approximately $70 \%$ (Fig. 6A) and this gave a HQL of 4-6 months. Based on sensory evaluation we suggest a WHC index of $55 \%$ and this resulted in a PSL of 12 months when stored at $-20{ }^{\circ} \mathrm{C}$. Lowering the temperature to $-40{ }^{\circ} \mathrm{C}$ increased both the $\mathrm{HQL}$ and PSL to $>12$ months. A similar trend was seen by Burgaard \& Jørgensen (2010) with a HQL/PSL of $4 / 12-15$ months at $-20{ }^{\circ} \mathrm{C}$ that increased to $>18$ months for both $\mathrm{HQL}$ and PSL at a storage temperature of $-30{ }^{\circ} \mathrm{C}$. The change of temperature from $-20^{\circ} \mathrm{C}$ to $-30^{\circ} \mathrm{C}$ as the critical range was supported by stabilisation of water loss when lowering the storage temperature to $-30^{\circ} \mathrm{C}$ as shown by (Schubring, 2005).

The frozen HQL shelf-life of cod as determined by sensory changes was three to six months for cod at $-20^{\circ} \mathrm{C}$ whereas the measured values for WHC and SSP, used as indices of spoilage, indicate a HQL of four to six months (Table 1). We suggest the sensory changes for the metallic, sweet, fishy and bitter taste attributes defined the PSL. Storage at $-20{ }^{\circ} \mathrm{C}$ gave a PSL of nine to 15 months depending on fishing methods and $>15$ months by lowering the temperature (Table 1 ). Further studies are needed on the correlation between sensory changes and levels of WHC and SSP in frozen cod to give a better criterion for HQL and PSL.

To accommodate the market demand for more convenience products, refreshed cod fillet (frozen and thawed) can supply the market with ready-to-use fish product. The CBA method would be recommended as filleting in the pre-rigor mortis phase gives a higher sensory score for the refreshed cod after five days chilled storage regardless of the frozen storage period (Martinsdottir \& Magnusson, 2001). As to the use of lower freezing storage temperatures in order to preserve the protein structure and thereby the textural quality this could have an adverse effect on the refreshed product as it has been shown that keeping cod at $-30{ }^{\circ} \mathrm{C}$, also protect the microbiota of the fish (Bøknæs et al. 2002; Emborg, Laursen, Rathjen, \& Dalgaard, 2002). Sørensen et al. (2020b) found a 15 days safe shelf-life of chilled MAP CBA cod, after frozen storage at $-20{ }^{\circ} \mathrm{C}$ for five months. Accurate recommendation to the industry of an optimal frozen storage period and temperature for refreshed cod, require further studies 
with different combinations of freezing periods, temperatures and sensory scores at chilled condition after thawing.

\section{Conclusion}

The CBA method results in a product with better durability in the sensory and colour quality. Initially and throughout the storage period, the CBA method gave a more firm fillet, and the better bleeding procedure resulted in a whiter fillet with a lower blood content. The conventional method gave a lower texture score at the end of the frozen storage, and they were rated lower for flakiness, juiciness for the cooked fillet, and higher for a metallic taste. The frozen storage temperature had an impact on the frozen shelf-life. Storage at $-20{ }^{\circ} \mathrm{C}$ gave a $\mathrm{HQL}$ of three to six months, determined by sensory evaluation and supported by WHC and SSP. Lowering the storage temperature to $-40{ }^{\circ} \mathrm{C}$, extended the $\mathrm{HQL}$ to $>15$ months.

\section{Acknowledgement}

Innovation Fund Denmark (grant no. 5189-00175B) funded this research. We thank employees at the processing plant in Maniitsoq, Greenland for their assistance, the local fisherman to supply us with the material and the sensory panellist at Royal Greenland for their time to evaluated cod samples, with a special thanks to Jan Zoutenbier for all the practical work associated with the sensory evaluation.

\section{References}

Ageeva, T. N., Jobling, M., Olsen, R. L., \& Esaiassen, M. (2017). Gender-specific responses of mature 
Atlantic cod (Gadus morhua L.) to feed deprivation. Fisheries Research, 188, 95-99. https://doi.org/10.1016/j.fishres.2016.12.010

Ageeva, T. N., Olsen, R. L., Joensen, S., \& Esaiassen, M. (2018). Quality aspects of fillet, loin and tail products made from live-stored feed-deprived Atlantic cod (Gadus morhua L.) at different times post mortem. Lwt, 97(9291), 656-661. https://doi.org/10.1016/j.Iwt.2018.06.031

Badii, F., \& Howell, N. K. (2002a). A comparison of biochemical changes in cod (Gadus morhua) and haddock (Melanogrammus aeglefinus) fillets during frozen storage. Journal of the Science of Food and Agriculture, 82(1), 87-97. https://doi.org/10.1002/jsfa.998

Badii, F., \& Howell, N. K. (2002b). Effect of antioxidants, citrate, and cryoprotectants on protein denaturation and texture of frozen cod (Gadus morhua). Journal of Agricultural and Food Chemistry, 50(7), 2053-2061. https://doi.org/10.1021/jf010824f

Bøgh-Sørensen, L. (2006). Recommendations for the Processing and Handling of Frozen Foods. (4th ed.). France: International Institute of Refrigeration (IIR).

Bøknæs, N., Guldager, H. S., Østerberg, C., \& Nielsen, J. (2001). Production of high quality frozen cod ( Gadus morhua ) fillets and portions on a freezer trawler. Journal of Aquatic Food Product Technology, 10, 33-47.

Bøknæs, N., Jensen, K. N., Guldager, H. S., Østerberg, C., Nielsen, J., \& Dalgaard, P. (2002). Thawed chilled Barents Sea cod fillets in modified atmosphere packaging-application of multivariate data analysis to select key parameters in good manufacturing practice. $L W T$ - Food Science and Technology, 35(5), 436-443. https://doi.org/8

Burgaard, M. G., \& Jørgensen, B. M. (2010). Effect of temperature on quality-related changes in cod (Gadus morhua) during short- and long-term frozen storage. Journal of Aquatic Food Product 
Technology, 19(3-4), 249-263. https://doi.org/10.1080/10498850.2010.510944

Chandra, M. V., \& Shamasundar, B. A. (2015). Texture profile analysis and functional properties of gelatin from the skin of three species of fresh water fish. International Journal of Food Properties, 18(3), 572-584, https://doi.org/10.1080/10942912.2013.845787

Careche, M., Del Mazo, M. L., Torrejón, P., \& Tejada, M. (1998). Importance of Frozen Storage Temperature in the Type of Aggregation of Myofibrillar Proteins in Cod (Gadus morhua) Fillets. Journal of Agricultural and Food Chemistry, 46(4), 1539-1546. https://doi.org/10.1021/jf970841y

Cole, S. C. (1990). Cod, God, Country and Family. Maritime Studies, 3(1), 1-29.

Del Mazo, M. L., Torrejón, P., Careche, M., \& Tejada, M. (1999). Characteristics of the salt-soluble fraction of hake (Merluccius merluccius) fillets stored at -20 and $-30^{\circ} \mathrm{C}$. Journal of Agricultural and Food Chemistry, 47(4), 1372-1377. https://doi.org/10.1021/jf9807420

Dyer, W. J., French, H. V., \& Snow, J. M. (1950). Proteins in Fish Muscle.: I. Extraction of Protein Fractions in Fresh Fish. Journal of the Fisheries Research Board of Canada, 7d(10), 585-593. https://doi.org/10.1139/f47-052

Eide, O., Børresen, T., \& Strøm, T. (1982). Minced Fish Production From Capelin (Mallotus villosus). A New Method for Gutting, Skinning and Removal of Fat from Small Fatty Fish Species. Journal of Food Science, 47(2), 347-349. https://doi.org/10.1111/j.1365-2621.1982.tb10078.x

Emborg, J., Laursen, B. G., Rathjen, T., \& Dalgaard, P. (2002). Microbial spoilage and formation of biogenic amines in fresh and thawed modified atmosphere-packed salmon (Salmo salar) at $2^{\circ} \mathrm{C}$. Journal of Applied Microbiology, 92(4), 790-799. https://doi.org/10.1046/j.13652672.2002.01588.x

Erikson, U., Lambooij, B., Digre, H., Reimert, H. G. M., Bondø, M., \& van der Vis, H. (2012). Conditions for 
instant electrical stunning of farmed Atlantic cod after de-watering, maintenance of unconsciousness, effects of stress, and fillet quality - A comparison with AQUI-S ${ }^{\mathrm{TM}}$. Aquaculture, 324-325, 135-144. https://doi.org/10.1016/j.aquaculture.2011.10.011

Erikson, Ulf, Digre, H., \& Misimi, E. (2011). Effects of Perimortem Stress on Farmed Atlantic Cod Product Quality: A Baseline Study. Journal of Food Science, 76(4). https://doi.org/10.1111/j.17503841.2011.02141.x

Etheridge, R. D., Pesti, G. M., \& Foster, E. H. (1998). A comparison of nitrogen values obtained utilising the Kjeldahl nitrogen and Dumas combustion methodologies (Leco CNS 2000) on samples typical of an animal nutrition analytical laboratory. Animal Feed Science and Technology, 73(1-2), 21-28. https://doi.org/10.1016/S0377-8401(98)00136-9

FAO. (2020). FAO Fisheries \& Aquaculture - Species Fact Sheets - Gadus morhua (Linnaeus, 1758). Retrieved January 26, 2020, from http://www.fao.org/fishery/species/2218/en

Godiksen, H., Hyldig, G., \& Jessen, F. (2003). Sarcoplasmic Reticulum Ca2+-ATPase and Cytochrome Oxidase as Indicators of Frozen Storage in Cod (Gadus morhua). Journal of Food Science, 68(8), 2579-2585. https://doi.org/10.1111/j.1365-2621.2003.tb07064.x

Henriksen, E., Heide, M., Hansen, Ø. J., \& Mortensen, A. (2018). Kunnskaps- og erfaringsgrunnlag for torskeoppdrett.

Hermansen, $\varnothing$., \& Eide, A. (2013). Bioeconomics of Capture-Based Aquaculture of Cod (Gadus Morhua). Aquaculture Economics and Management, 17(1), 31-50. https://doi.org/10.1080/13657305.2013.747225

Hibberd, M. G., \& Trentham, D. R. (1986). Relationships between chemical and mechanical events during muscular contraction. The Annual Review of Biophysics, 15, 119-161. 
https://doi.org/10.1146/annurev.bb.15.060186.001003

Hultmann, L., Phu, T. M., Tobiassen, T., Aas-Hansen, O., \& Rustad, T. (2012). Effects of pre-slaughter stress on proteolytic enzyme activities and muscle quality of farmed Atlantic cod (Gadus morhua). Food Chemistry, 134(3), 1399-1408. https://doi.org/10.1016/j.foodchem.2012.03.038

Huss, H. H. (1995). Quality and quality changes in fresh fish. Rome: FAO fisheries technical paper 348.

Jobling, M. (1981). The influences of feeding on the metabolic rate of fishes: a short review: NOTE ADDED IN PROOF. Journal of Fish Biology, 18(5), 615-615. https://doi.org/10.1111/j.10958649.1981.tb03802.x

Jørpeland, G., Imsland, A., Stien, L. H., Bleie, H., \& Roth, B. (2015). Effects of filleting method, stress, storage and season on the quality of farmed Atlantic cod ( Gadus morhua L.). Aquaculture Research, 46(7), 1597-1607. https://doi.org/10.1111/are.12312

Kristoffersen, S., Tobiassen, T., Steinsund, V., \& Olsen, R. L. (2006). Slaughter stress, postmortem muscle $\mathrm{pH}$ and rigor development in farmed Atlantic cod (Gadus morhua L.). International Journal of Food Science and Technology, 41(7), 861-864. https://doi.org/10.1111/j.1365-2621.2005.01149.x

LeBlanc, E. L., \& LeBlanc, R. J. (1988). Effect of frozen storage temperature on free and bound formaldehyde content of god (Gadus morhua) fillets. 12, 95-113. https://doi.org/10.1111/j.17454549.1988.tb00070.x

LeBlanc, E. L., \& LeBlanc, R. J. (1992). Determination of hydrophobicity and reactive groups in proteins of cod (Gadus morhua) muscle during frozen storage. Food Chemistry, 43(1), 3-11. https://doi.org/10.1016/0308-8146(92)90234-S

LeBlanc, E. L., LeBlanc, R. J., \& Blum, I. E. (1988). Prediction of Quality in Frozen Cod (Gadus morhua) Fillets. Journal of Food Science, 53(2), 328-340. https://doi.org/10.1111/j.1365- 
2621.1988.tb07700.x

Martinsdottir, E., \& Magnusson, H. (2001). Keeping Quality of Sea-Frozen Thawed Cod Fillets on Ice. Journal of Food Science, 66(9), 1402-1408. https://doi.org/10.1111/j.1365-2621.2001.tb15222.x

Mørkøre, T., Hansen, S. J., \& Rørvik, K. (2006). Relevance of storage temperature for contraction and gaping of pre rigor filleted farmed cod (Gadus morhua L.). In J. B. Luten, C. Jacobsen, K. Bekaert, A. Sæbø, \& J. Oehlenschläger (Eds.), Seafood research from fish to dish. Wageningen: Wageningen Academic.

Olsen, S. H., Joensen, S., Tobiassen, T., Heia, K., Akse, L., \& Nilsen, H. (2014). Quality consequences of bleeding fish after capture. Fisheries Research, 153, 103-107. https://doi.org/10.1016/j.fishres.2014.01.011

Olsen, S. H., Tobiassen, T., Akse, L., Evensen, T. H., \& Midling, K. T. (2013). Capture induced stress and live storage of Atlantic cod (Gadus morhua) caught by trawl: Consequences for the flesh quality. Fisheries Research, 147, 446-453. https://doi.org/10.1016/j.fishres.2013.03.009

Olsson, G. B., Gundersen, B., \& Esaiassen, M. (2006). Pre-slaughter starvation of farmed Atlantic cod fed vegatable proteins: Effects on quality parameters. In J. B. Luten, C. Jacobsen, K. Bekaert, A. Sæbø, \& J. Oehlenschläger (Eds.), Seafood research from fish to dish (pp. 139-148). Wageningen: Wageningen Academic.

PanelCheck. (2012). PanelCheck. Retrieved December 11, 2019, from http://www.panelcheck.com/

Ratkowsky, D. A., Olley, J., McMeekin, T. A., \& Ball, A. (1982). Relationship between temperature and growth rate of bacterial cultures. Journal of Bacteriology, 149(1), 1-5. https://doi.org/10.1128/jb.149.1.1-5.1982

Rehbein, H. (1988). Relevance of trimethylamine oxide demethylase activity and haemoglobin content 
to formaldehyde production and texture deterioration in frozen stored minced fish muscle. Journal of the Science of Food and Agriculture, 43(3), 261-276. https://doi.org/10.1002/jsfa.2740430308

Schubring, R. (2005). Changes in texture, water holding capacity, colour and thermal stability of frozen cod (Gadus morhua) fillets: Effect of frozen storage temperature. Deutsche LebensmittelRundschau, 101(11), 484-493.

Skjelvareid, M. H., Heia, K., Olsen, S. H., \& Stormo, S. K. (2017). Detection of blood in fish muscle by constrained spectral unmixing of hyperspectral images. Journal of Food Engineering, 212, 252-261. https://doi.org/10.1016/j.jfoodeng.2017.05.029

Sønvisen, S. A., \& Standal, D. (2019). Catch-based aquaculture in Norway - Institutional challenges in the development of a new marine industry. Marine Policy, 104(April 2018), 118-124. https://doi.org/10.1016/j.marpol.2019.02.039

Sørensen, J. S., Bøknæs, N., Mejlholm, O., \& Dalgaard, P. (2020a). Superchilling in combination with modified atmosphere packaging resulted in long shelf-life and limited microbial growth in Atlantic cod (Gadus morhua L .) from capture-based-aquaculture in Greenland. Journal Of Food Microbiology, 88(December 2019), 103405. https://doi.org/10.1016/j.fm.2019.103405

Sørensen, J. S., Ørnfeld-Jensen, O., Bøknæs, N., Mejlholm, O., Jessen, F., \& Dalgaard, P. (2020b). Thawed and chilled Atlantic cod (Gadus morhua L.) from Greenland - Options for improved distribution. LWT - Food Science and Technology. In press https://doi.org/10.1016/i.Iwt.2020.109473

Statistics Greenland. (2019). Total landings of fish and shellfish by time, municipality, species, unit and month [FIE001]. Retrieved August 9, 2019, from FIX001 website: http://bank.stat.gl/pxweb/da/Greenland/Greenland_FI_FI10/FIX001.px/chart/chartViewLine/?rx id=FIX00109-08-2019 07:30:24 
Stone, H., Sidel, J., Oliver, S., Woolsey, A., \& Singleton, R. (1974). Sensory evaluation by quantitative descriptive analysis. Food Technology, 28(11), 24-33.

the Farm Animal Welfare Committee (FAWC). (2014). Opinion on the welfare of farmed fish at the time of killing welf. London.

Torry Research Station. (2001). Cold storage of frozen fish. Retrieved January 26, 2020, from Torry advisory note No. 28 website: http://www.fao.org/3/x5907e/x5907e00.htm

Waagb $\varnothing$, R., Jørgensen, S. M., Timmerhaus, G., Breck, O., \& Olsvik, P. A. (2017). Short-term starvation at low temperature prior to harvest does not impact the health and acute stress response of adult Atlantic salmon. PeerJ, 2017(4), 1-22. https://doi.org/10.7717/peerj.3273 
Fig. 1. Illustration of the capture-based aquaculture fishery method. The Atlantic cod was captured inshore by pond nets (A) similar to the conventional fishery. The cod was transferred without leaving the water to net enclosures and hold for two to three weeks without feeding (B). The cod, now without gastrointestinal content, was pumped into a well-boat (C) and transported alive to a processing plant, where the cod kept into large net enclosures until processed (D).

Fig 2. Photo of cod fillet showing the position of the sampling area for hyperspectral imaging ( $A$ and $B$ ), texture analysing $(A)$, water holding capacity $(A)$, salt soluble proteins $(A)$.

Fig. 3. Principal component analysis of the sensory profile scores for the two fishing methods, A (scores), conventional storage at $-20^{\circ} \mathrm{C}$ (i) and capture-based aquaculture (CBA) at $-20^{\circ} \mathrm{C}$ (ii), $-40{ }^{\circ} \mathrm{C}$ (iii) and $-80{ }^{\circ} \mathrm{C}$ (iv) for a storage period of 15 months $(\mathrm{m})$. Circles highlight the samples storage after 12 and 15 months for each treatment. Loadings (B) based on the 14 words of the sensory profile, for the raw fillet appearance (A) (gaping, whiteness, frayed, firmness), odour (O) (fishy, ocean/seaweed) and for the cooked fillet $(O)$ (warm milky), texture $(T)$ (juiciness, toughness, flakiness) and flavour (F) (sweet, metallic, fishiness, bitter).

Fig. 4. Sensory scores for three texture parameters of the cooked cod, flakiness (A), juiciness (B) and toughness $(C)$, two taste parameters of the cooked cod, metallic (D) and sweet (E) and the appearance parameter of the raw cod, firmness $(\mathrm{F})$. Conventional cod storage at $-20^{\circ} \mathrm{C}$ was indicated by $\bullet$ and capture-based aquaculture storage at $-20^{\circ} \mathrm{C}(\Delta),-40{ }^{\circ} \mathrm{C}(\mathbf{a})$ and $-80^{\circ} \mathrm{C}(0)$. Symbols and error bars indicate Avg. \pm SEM.

Fig. 5. Blood concentration images of one filet from the conventional fishing method $(A)$ and from the capture-based aquaculture fishing method (B). The corresponding colour image of fillets were presented in C-D. The images are representative of the 16 fillets studied.

Fig. 6. Water holding capacity (A) and salt soluble proteins (B) during 12 months of frozen storage for conventionally processed $\operatorname{cod}(\bullet)$ stored at $-20^{\circ} \mathrm{C}$ and capture-based aquaculture cod stored at $-20^{\circ} \mathrm{C}$ $(\Delta),-40^{\circ} \mathrm{C}(\mathbf{\square})$ and $-80^{\circ} \mathrm{C}(\diamond)$. Symbols and error bars indicate Avg. \pm SEM. 
Table 1: Frozen shelf-life of Atlantic cod based on sensory evaluation and indices of spoilage.

\begin{tabular}{|c|c|c|c|c|c|c|c|}
\hline & \multicolumn{7}{|c|}{ Shelf-life (months) } \\
\hline & \multicolumn{2}{|c|}{ Sensory } & \multicolumn{2}{|c|}{$\begin{array}{ll}\text { Water holding } \\
\text { capacity }\end{array}$} & \multicolumn{3}{|c|}{ Salt soluble protein } \\
\hline Cod fishing and processing method & $\mathrm{HQL}^{a}$ & $\mathrm{PSL}^{b}$ & $\begin{array}{r}\mathrm{HQL} \\
>65 \%)^{\prime}\end{array}$ & $\mathrm{PSL}(<55 \%)$ & HQL (> & $70 \%)$ & PSL $(<55 \%)$ \\
\hline Conventional at $-20^{\circ} \mathrm{C}$ & $3-6$ & $9-12$ & 6 & 12 & & 5 & $11-12$ \\
\hline Capture-based aquaculture at $-20^{\circ} \mathrm{C}$ & $3-6$ & $12-15$ & $4-5$ & 12 & & 4 & $10-11$ \\
\hline Capture-based aquaculture at $-40{ }^{\circ} \mathrm{C}$ & $>15$ & $>15$ & & $>12$ & & $>12$ & $>12$ \\
\hline
\end{tabular}

${ }^{a}$ Just notable different, for the 13 sensory attributes.

${ }^{b}$ Time to reach a significant different for metallic, sweet and bitter taste attributes. 
Table 2: Effect of frozen storage on dry matter, texture and colour values for of cod fillet produced with conventional or capture-based aquaculture fishery and processing methods.

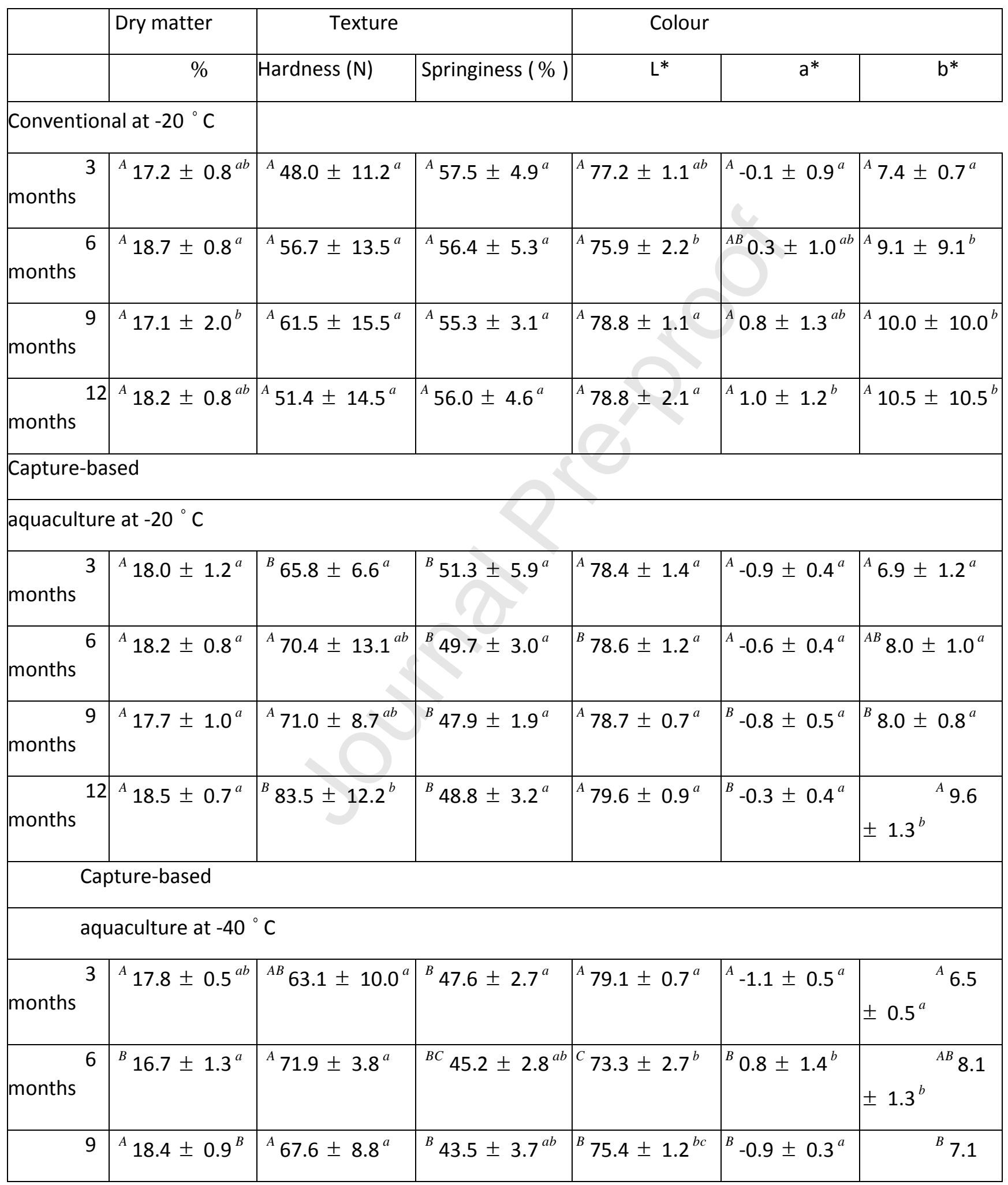




\section{Journal Pre-proof}

\begin{tabular}{|c|c|c|c|c|c|c|}
\hline months & & & & & & $\pm 1.3^{a b}$ \\
\hline months & ${ }^{A} 18.1 \pm 0.7^{b}$ & ${ }^{B} 71.4 \pm 11.2^{a}$ & ${ }^{C} 40.8 \pm 3.1^{b}$ & $B^{B} 76.5 \pm 1.1^{c}$ & ${ }^{B}-1.0 \pm 0.6^{a}$ & $\begin{array}{r}{ }^{B} 6.7 \\
\pm 1.1^{a b}\end{array}$ \\
\hline \multicolumn{7}{|c|}{ Capture-based } \\
\hline \multicolumn{7}{|c|}{ aquaculture at $-80^{\circ} \mathrm{C}$} \\
\hline months 3 & ${ }^{A} 17.1 \pm 1.0^{a}$ & ${ }^{B} 68.9 \pm 11.7^{a}$ & ${ }^{B} 49.0 \pm 5.1^{a}$ & ${ }^{A} 79.3 \pm 1.4^{a}$ & ${ }^{A}-1.1 \pm 0.3^{a}$ & ${ }^{A} 6.2 \pm 0.9^{a b}$ \\
\hline months & ${ }^{A B} 18.0 \pm 1.4^{a}$ & ${ }^{A} 70.4 \pm 10.6^{a}$ & ${ }^{c} 40.9 \pm 3.0^{b}$ & ${ }^{A B} 76.8 \pm 1.1^{b}$ & ${ }^{A}-0.5 \pm 0.5^{a}$ & ${ }^{B} 7.5 \pm 1.4^{a b}$ \\
\hline months & ${ }^{A} 17.5 \pm 1.0^{a}$ & ${ }^{A} 66.5 \pm 11.5^{a}$ & ${ }^{B} 44.0 \pm 2.3^{a b}$ & ${ }^{B} 76.0 \pm 1.9^{b}$ & ${ }^{B}-0.5 \pm 0.5^{a}$ & ${ }^{B} 7.5 \pm 0.5^{a}$ \\
\hline months & ${ }^{A} 17.8 \pm 0.9^{a}$ & ${ }^{B} 77.8 \pm 14.8^{a}$ & ${ }^{B C} 45.7 \pm 4.2^{a b}$ & ${ }^{A B} 77.8 \pm 0.9^{a b}$ & ${ }^{B}-1.2 \pm 0.2^{a}$ & ${ }^{B} 6.0 \pm 0.8^{b}$ \\
\hline
\end{tabular}

${ }^{a-b}$ Lower case indicate significant differences $(p<0.05)$ within the treatment as changes in relation to time.

${ }^{A-C}$ Upper case letters indicate significant differences $(p<0.05)$ between the treatments and within for the same storage period. 


\section{CRediT author statement}

Jonas Steenholdt Sørensen: Conceptualisation, Investigation, Writing - Original Draft, Writing - Review \& Editing Niels Bøknæs: Conceptualisation, Resources Ole Mejlholm: Conceptualisation, Resources, Karsten Heia: Formal analysis, Visualization Paw Dalgaard: Writing - Review \& Editing and Flemming Jessen: Resources, Conceptualisation, Supervision, Writing - Review \& Editing 


\section{Declaration of interests}

$\square$ The authors declare that they have no known competing financial interests or personal relationships that could have appeared to influence the work reported in this paper.

$\bigotimes$ The authors declare the following financial interests/personal relationships which may be considered as potential competing interests:

Jonas Steenholdt Sørensen, Niels Bøknæs and Ole Mejlholm are employed by Royal Greenland. 
Highlights

- Capture-based aquaculture (CBA) production of cod improve fillet texture

- Blood content in cod fillets was reduced by changing to CBA production

- Indices of spoilage for high quality frozen sensory shelf-life was suggested 


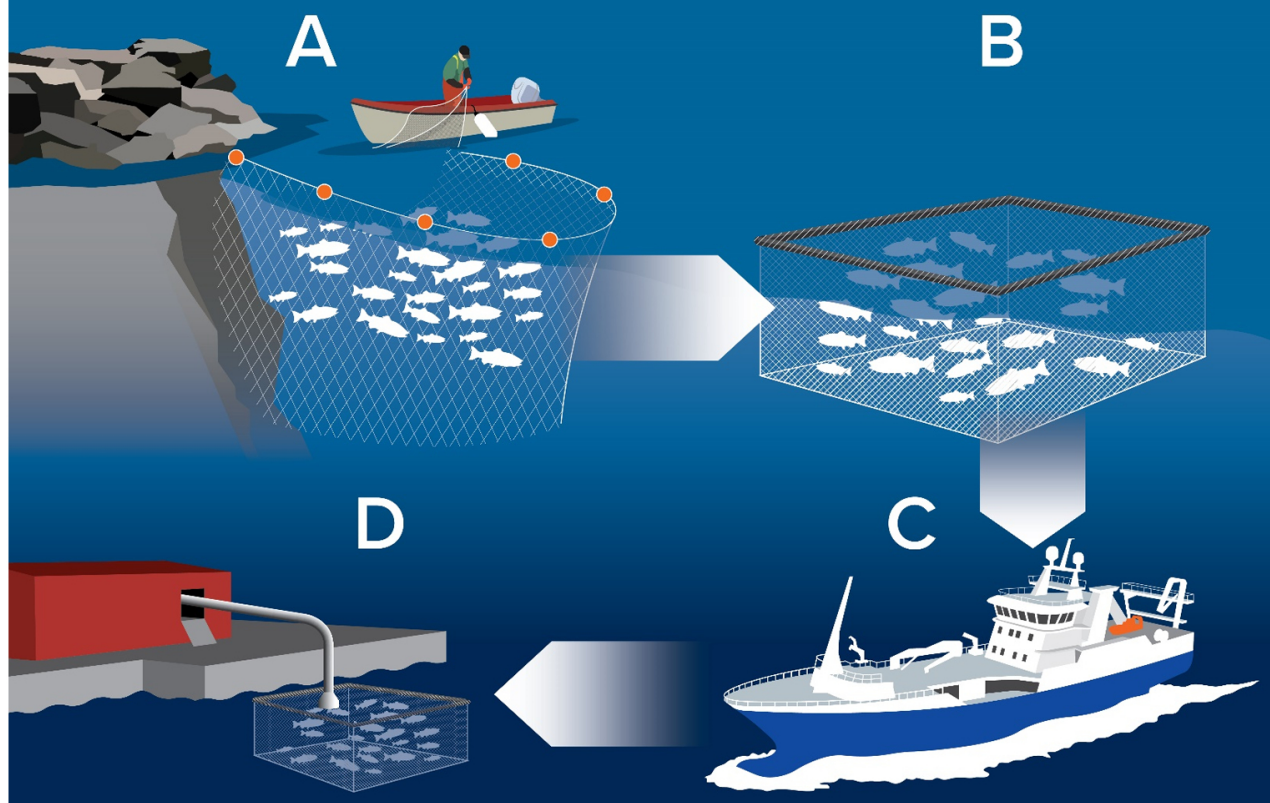

Figure 1 


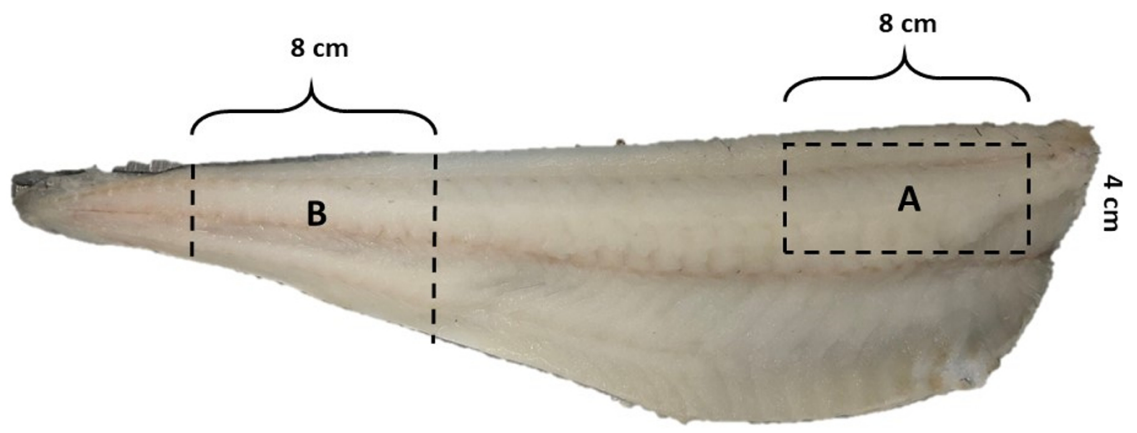

Figure 2 


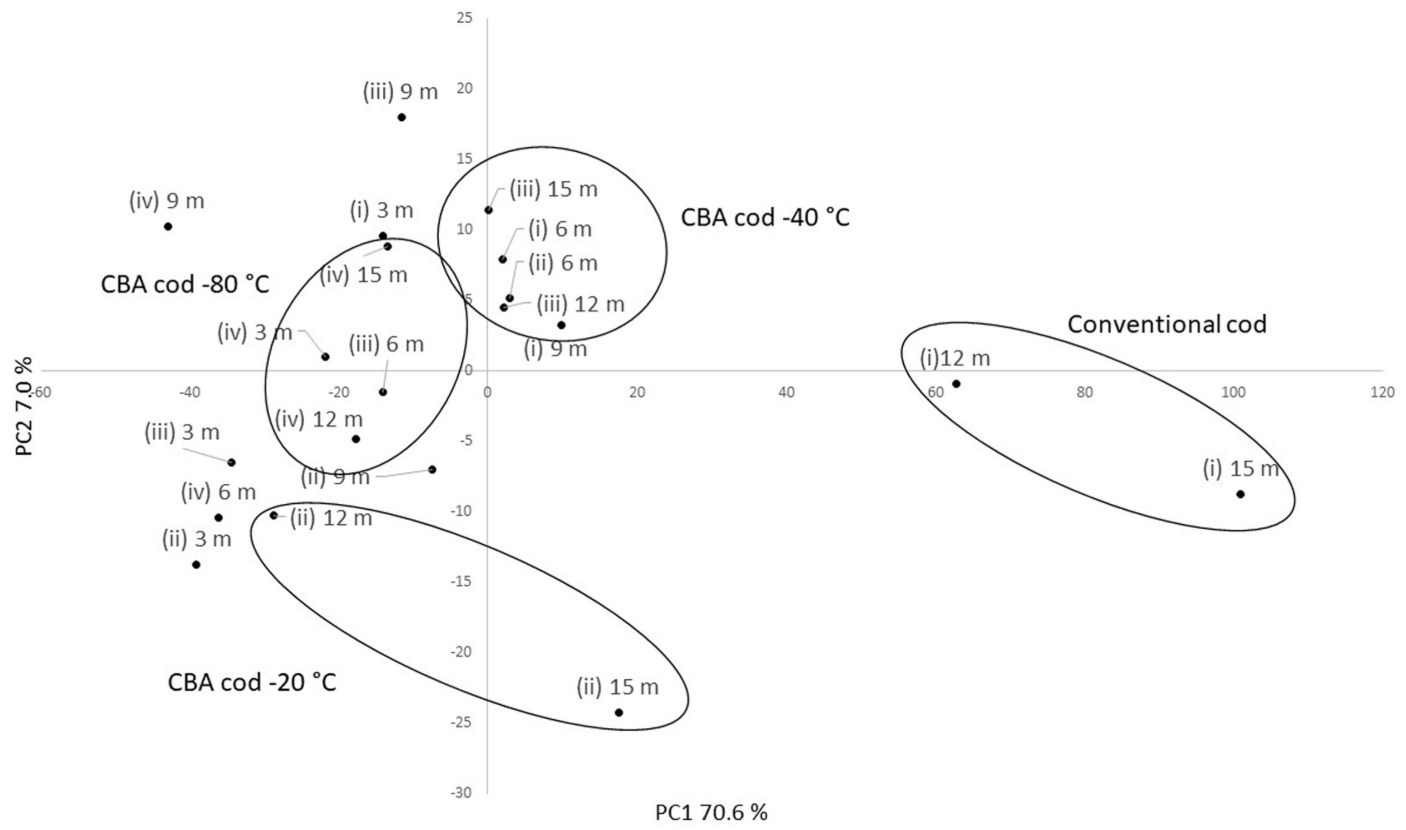

A

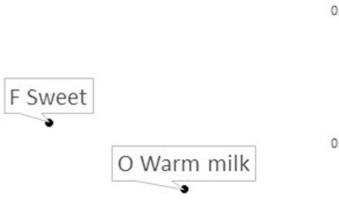

T Flakiness

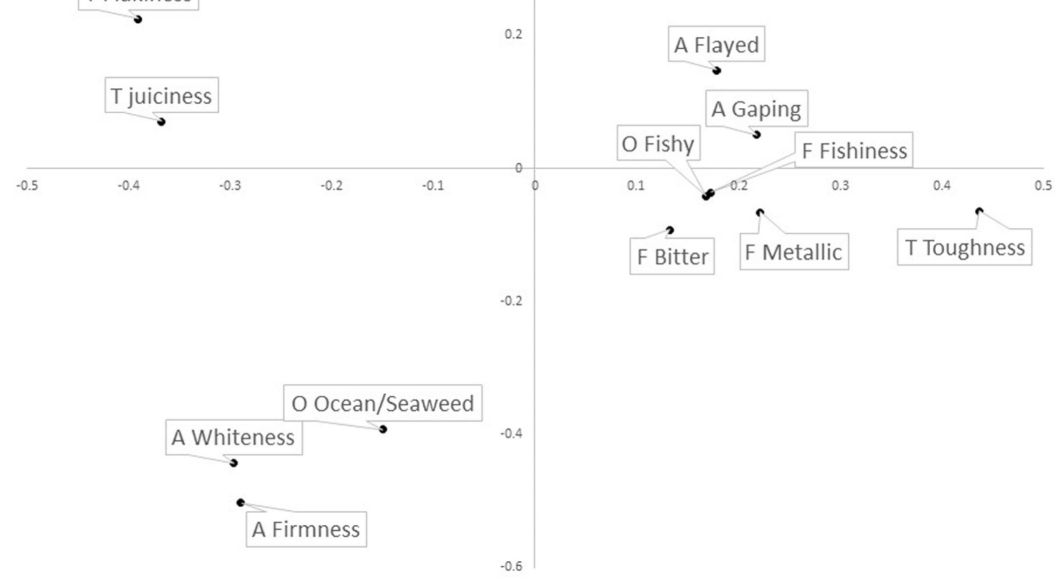

Figure 3 

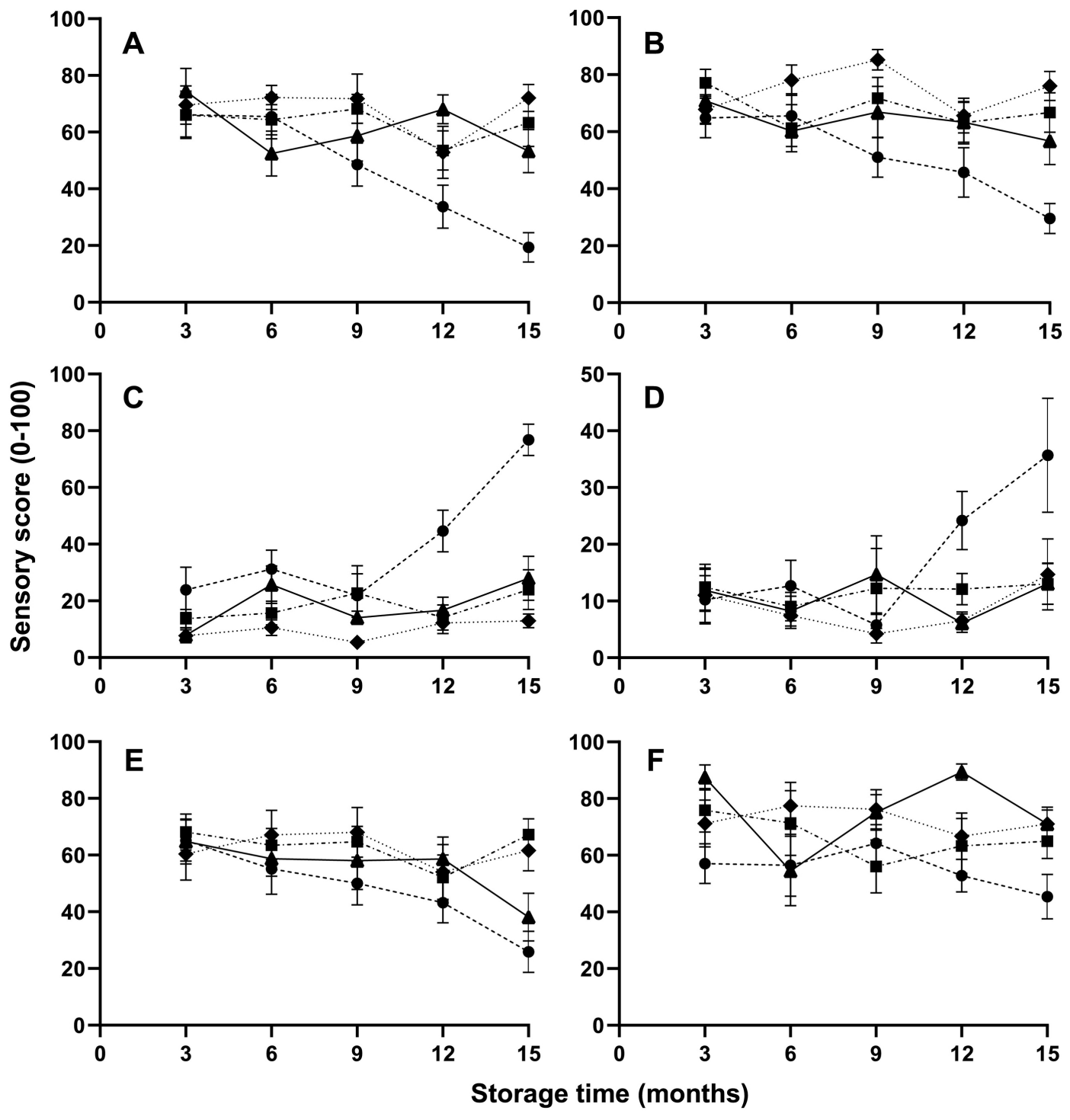

Figure 4 

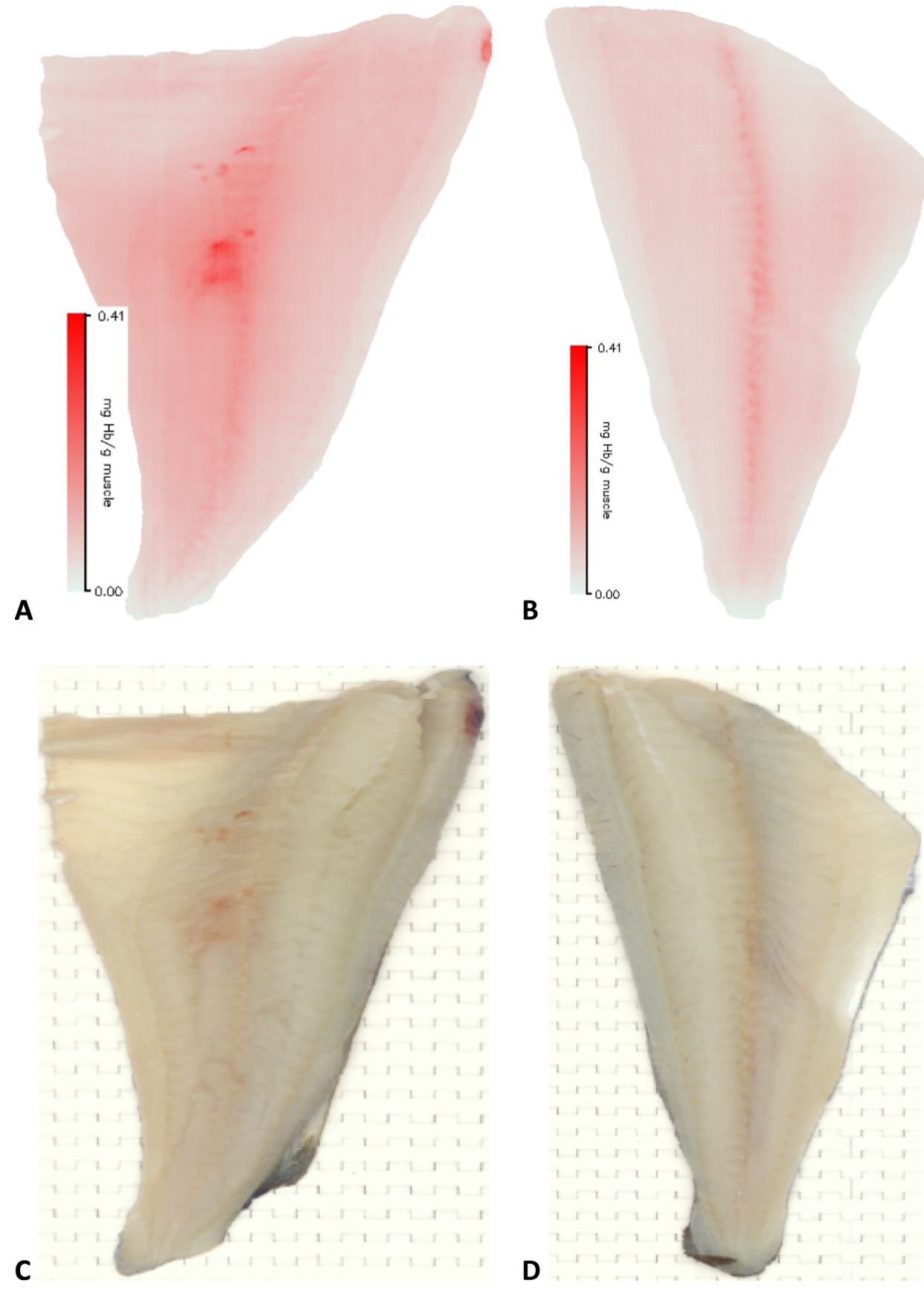

Figure 5 


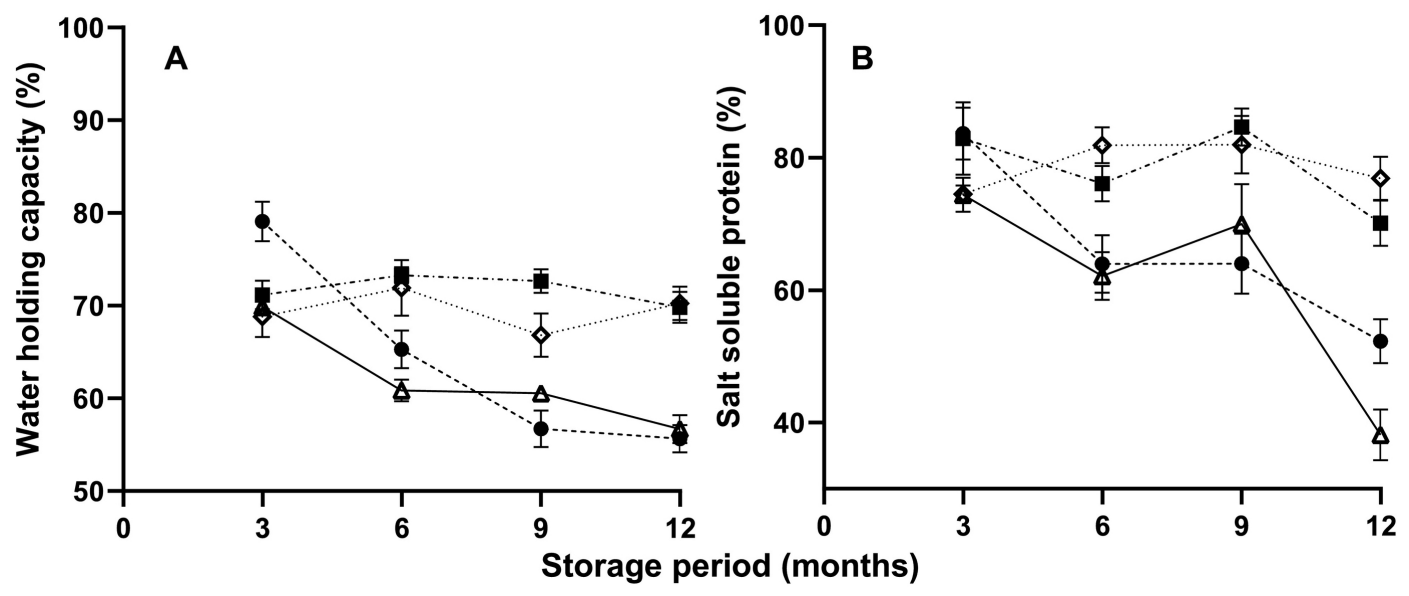

Figure 6 